\title{
Petroleum extracts of Cynanchum cutum L. and structure elucidation of isolated
}

\section{compounds}

Available online at www.ijistweb.com

RESEARCH ARTICLE

Rajni Singh Khureja*, Dinesh Kumar

Department of Chemistry, University Teaching Department, Sri Satya Sai University of

Technology \& Medical Sciences, Pachama, Sehore-466001-MP, India.

*Corresponding Author's E-mail: om11agra85@gmail.com

DOI: $10.22270 /$ ijist.v4i1.34

\section{ABSTRACT}

In present study, petroleum ether extracts of Cynanchum cutum L. isolated unknown active constituents and their structure elucidated by analytical technique. The extracts were analyzed by the GC/MS technique. The GC chromatogram showed nine peaks corresponding to four compounds. These four compounds were identified on the basis of a high percentage of matching with authentic spectrum using NIST library.

Keywords: Structure Elucidation, Cynanchum cutum L., Natural Product, Petroleum Extracts.

\section{Introduction}

Presently numerous recent drugs are products of nature or resulting from natural products, and nature is an auspicious source of treatments for new and emerging medical conditions (1-3). The search for treatments for diseases or infection from nature preceded the discovery of new technologies like ultra-high throughput screening (uHTS), targeted drug delivery (4-5) combinatorial chemistry, and genomic technology (6-9). Drug discovery from natural products has however been impacted significantly by the evolution of these new technologies, and there is an emerging perception that the role of natural products is starting to diminish (10-12). In spite of this, plants are still capable of yielding new bioactive compounds, and microbial organisms continue to yield novel structures and novel bioactivities. Since only $10 \%$ of the world's biodiversity has been studied for potential curative entities, the remainder is waiting to be welcomed to the world of drug discovery (1314).

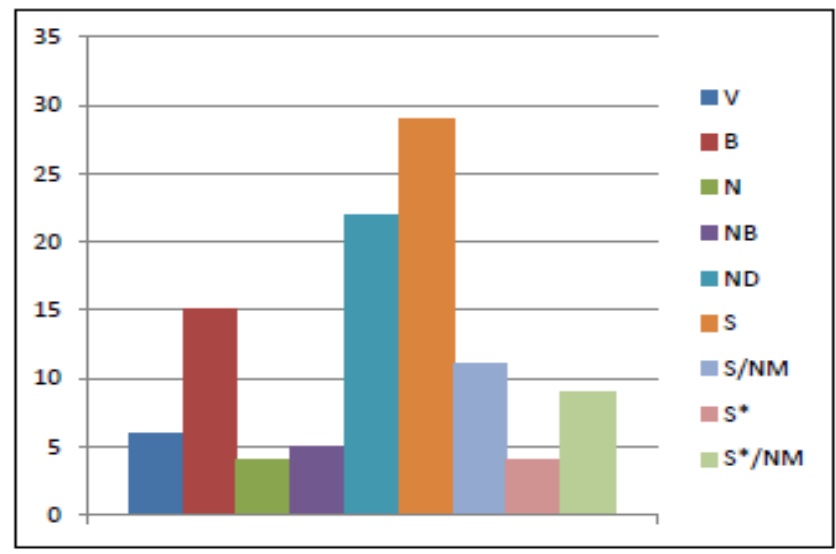

\begin{tabular}{l}
\hline $\mathrm{V}=$ Vaccines \\
$\mathrm{B}=$ Biologicals \\
$\mathrm{N}=$ Natural Products $(\mathrm{NP})$ \\
$\mathrm{NB}=\mathrm{NP}$ botanical \\
$\mathrm{ND}=$ Derived from NP \\
$\mathrm{S}=$ totally synthetic drug \\
$\mathrm{S} / \mathrm{NM}=$ synthetic but $\mathrm{NP}$ \\
mimic \\
$\mathrm{S}^{*}=$ synthetic but \\
pharmacophore is/was NP \\
$\mathrm{S}^{*} / \mathrm{NM}=\mathrm{S}^{*}$ with NP mimic
\end{tabular}

Figure 1. Source of new Drugs

The importance of natural products as a source of new drugs is shown in Figure 1, which documents the sources of all new drugs introduced between 1981 and 2010. The data clearly show the influence of nature in our discovery of new drug entities. About $29 \%$ of 
the drugs were of synthetic origin, and the major portion of the remainder either were from natural products or were derived from natural products or the pharmacophore was from a natural origin. Therefore, the fact that most of the new drug entities are directly or indirectly linked to Mother Nature cannot be ignored. The linking of products from nature to modern combinatorial synthesis is also on the rise and older drugs with new indications are mainly drugs from natural products or are derivatives of natural products. For example, a study showed that compounds active on tumor cells (15) also exhibited anxiolytic properties and inhibited HIV reverse transcriptase.

The major advantage of screening natural products is that they offer vast structural diversity, as compared with the more modest diversity obtained by combinatorial approaches.

\section{Materials and Methods}

The powdered air dried aerial parts of Cynanchum cutum L. was processed according to scheme 1 .

\section{Study of Petroleum Ether Fraction}

The petroleum ether fraction ( $c f$. scheme 1$)$ was evaporated to dryness where a dark green residue was obtained. The residue was saponified using alcoholic sodium hydroxide. The un-saponifiable material was subjected to column chromatograph using silica gel. Three fractions were obtained by the solvent system hexane / EtOAc containing compound 1 at ratio of 49:1, compound 2 at $24: 1$ and compounds 3 and 4 at 13:1.

\section{Characterization of Compound 1}

Thin- layer chromatographic study of compound 1 showed that it was not homogenous and contaminated with other minor constituents. Therefore, it was purified by preparative thin-layer chromatography, using silica gel and the same solvent system of CC (pet. ether / EtOAc 49:1). Compound 1 was obtained as white needles, m.p. $218-220^{\circ} \mathrm{C}, \mathrm{R}_{\mathrm{f}}$ $=0.24$ (silica gel, pet. ether / chloroform 3:4). It gave a violet color upon spraying with $p$ anisaldehyde sulphoric acid reagent indicating it's steroidal or triterpenoidal nature. 


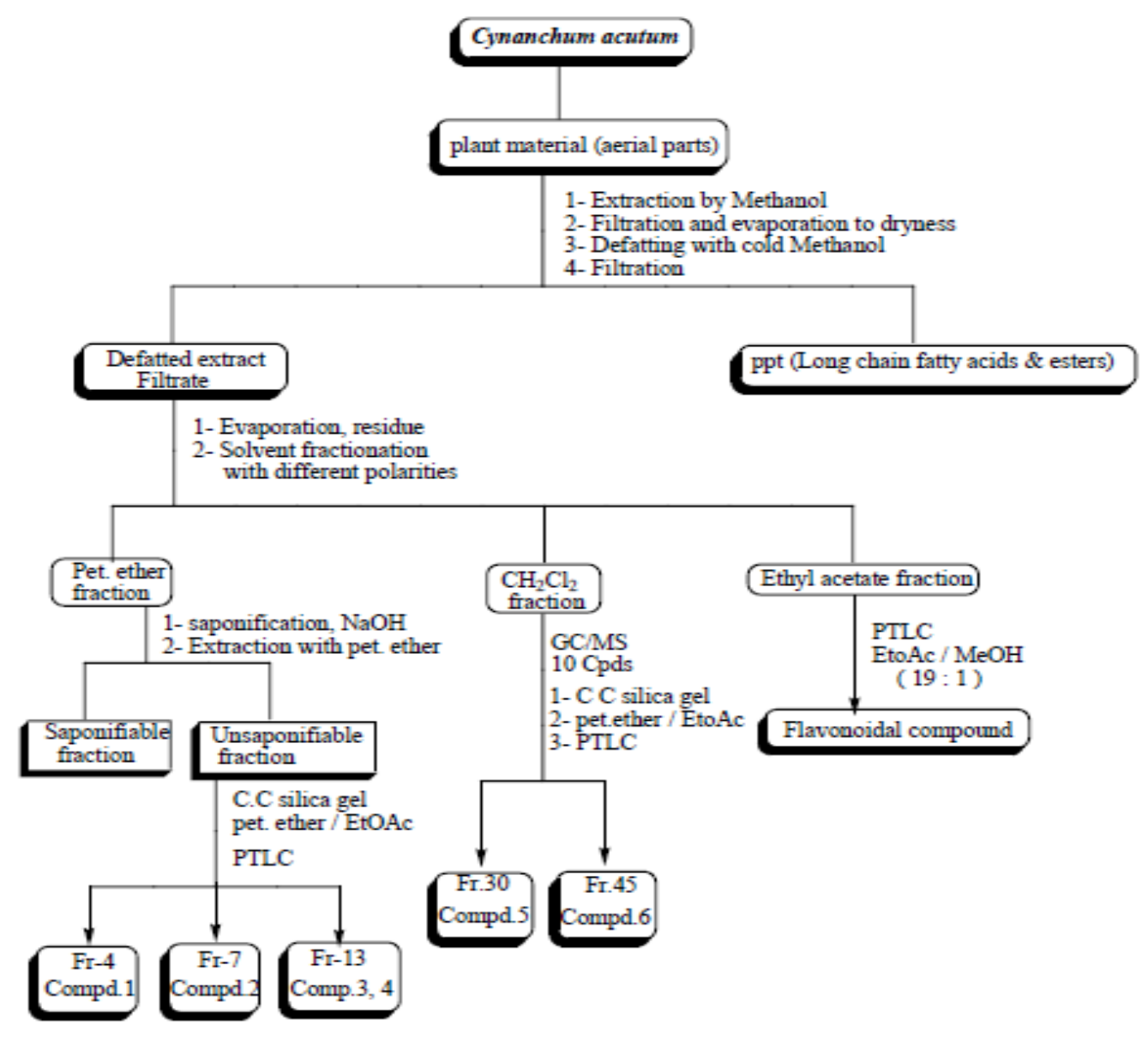

Figure 2. Scheme 1: Processing of Cynanchum acutum L.

\section{Results and discussion}

\section{Characterization of Compound 1}

The IR spectrum revealed the presence of absorption bands at $2985 \mathrm{~cm}^{-1}$ (CH-stretching), $1732 \mathrm{~cm}^{-1}$ (C=O group), $1252 \mathrm{~cm}^{-1}$ (C-O of acetate group). The ${ }_{1} \mathrm{H}$ NMR spectrum (table 4.1) revealed the presences of six methyl group signals in the up field region showing that the compound may be steroidal or triterpenoidal compound. The presence of two olefinic protons as broad singlets at 4.55 and $4.67 \mathrm{ppm}$ is characteristic for pentacyclic lupane triterpene series (H-29, 29'). A down field H-3 as double of doublet at $\delta 4.46 \mathrm{ppm}$ indicates the probable link to an ester group and this was confirmed by the presence of acetoxyl group as singlet at $3.6 \mathrm{ppm}$. An olefinic methyl group as a broad singlet at $1.67 \mathrm{ppm}$ was consistent to the C-30 methyl group. The H-19 appears as ddd at $2.38 \mathrm{ppm}$ due to its allylic position. The Me-23 and 24 appear as singlets at 0.94, 0.76 ppm, respectively. The spectrum indicated the Table $1{ }^{1} \mathrm{H}$ NMR of compound 1 presence of four tertiary methyl groups (Me-25, 26, 27, and 28) as singlets at 0.83, 1.03, 0.96, $0.79 \mathrm{ppm}$, respectively. Based on the previous spectral data, compound 1 which was isolated from unsaponifiable part is 3-O-acetyl lupane which was isolated previously from the same plant species by Halim and his team.

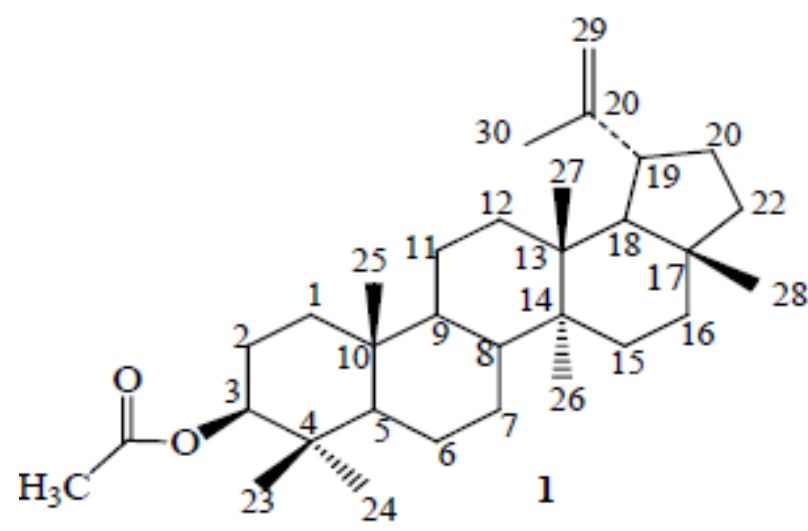




\begin{tabular}{|c|c|c|}
\hline \hline H atom & $\delta$ value, ppm & $\begin{array}{c}\text { Integration, multiplicity } \\
(\mathrm{J}, \mathrm{Hz})\end{array}$ \\
\hline 3 & 4.46 & $1 \mathrm{H}, \mathrm{dd}, 5.53$ \\
\hline 19 & 2.38 & $1 \mathrm{H}, \mathrm{ddd}, 10.6,10.6,5.3$ \\
\hline 23 & 0.94 & $3 \mathrm{H}, \mathrm{s}$ \\
\hline 24 & 0.76 & $3 \mathrm{H}, \mathrm{s}$ \\
\hline 25 & 0.83 & $3 \mathrm{H}, \mathrm{s}$ \\
\hline 26 & 1.03 & $3 \mathrm{H}, \mathrm{s}$ \\
\hline 27 & 0.96 & $3 \mathrm{H}, \mathrm{s}$ \\
\hline 28 & 0.79 & $3 \mathrm{H}, \mathrm{s}$ \\
\hline 29 & 4.55 & $1 \mathrm{H}, \mathrm{br} \mathrm{s}$ \\
\hline 29 & 4.67 & $1 \mathrm{H}, \mathrm{br} \mathrm{s}$ \\
\hline 30 & 1.67 & $3 \mathrm{H}, \mathrm{br} \mathrm{H}$ \\
\hline $\mathrm{CH}_{3} \mathrm{CO}$ & 3.6 & $3 \mathrm{H}, \mathrm{s}$ \\
\hline
\end{tabular}

\section{Characterization of Compound 2}

Compound 2 was isolated as white needle crystals, m.p. $211-213^{\circ} \mathrm{C}, \mathrm{R}_{\mathrm{f}}=0.24$ from (Silica Gel, pet. ether-chloroform 3:4). It gave a violet color upon spraying with $p$-anisaldehydesulphoric acid reagent indicating it's steroidal or tri-terpenoidal nature. The IR spectrum (Fig 5) revealed the presence of absorption bands at $3313 \mathrm{~cm}^{-1}$ (OH group), $2985 \mathrm{~cm}^{-1}$ (C-H stretching). The ${ }_{1} \mathrm{H}$ NMR spectrum of

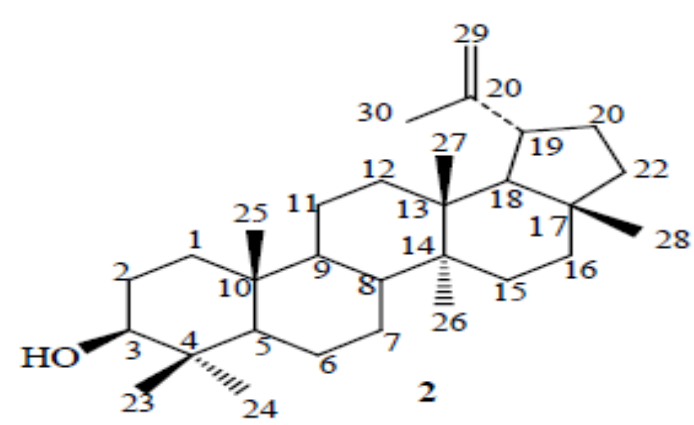

Table $2{ }^{1} \mathrm{H}$ NMR of compound 2 compound 2 (table 1 ) is identical with the ${ }_{1} \mathrm{H}$ NMR spectrum of compound 1 except the position of proton $\mathrm{H}-3$. H-3 appears as double of doublet at a chemical shift $3.2 \mathrm{ppm}$ which indicating that $\mathrm{H}-3$ is attached to a free hydroxyl group characteristic for $\mathrm{H}-3$ in sterols and triterpens. Thus compound 2 is lupan-3-ol which was isolated previously from the same plant species by Halim and his team.

\begin{tabular}{|c|c|c|}
\hline H atom & o value, ppm & $\begin{array}{c}\text { Integration, multiplicity } \\
(\mathrm{J}, \mathrm{Hz})\end{array}$ \\
\hline 3 & 4.46 & $1 \mathrm{H}, \mathrm{dd}, 5.53$ \\
\hline 19 & 2.38 & $1 \mathrm{H}, \mathrm{ddd}, 10.6,10.6,5.3$ \\
\hline 23 & 0.94 & $3 \mathrm{H}, \mathrm{s}$ \\
\hline 24 & 0.76 & $3 \mathrm{H}, \mathrm{s}$ \\
\hline 25 & 0.83 & $3 \mathrm{H}, \mathrm{s}$ \\
\hline 26 & 1.03 & $3 \mathrm{H}, \mathrm{s}$ \\
\hline 27 & 0.96 & $3 \mathrm{H}, \mathrm{s}$ \\
\hline 28 & 0.79 & $3 \mathrm{H}, \mathrm{s}$ \\
\hline 29 & 4.55 & $1 \mathrm{H}, \mathrm{br} \mathrm{s}$ \\
\hline 29 & 4.67 & $1 \mathrm{H}, \mathrm{br} \mathrm{H}$ \\
\hline 30 & 1.67 & $3 \mathrm{H}, \mathrm{b} \mathrm{s}$ \\
\hline
\end{tabular}

\section{Structure Elucidation of Compound 3}

Compound 3 was obtained as white needles, m.p. $138-139^{\circ} \mathrm{C}$; it gave a violet color upon spraying with $p$-anisaldehyde-sulphoric acid reagent indicating it's steroidal or triterpenoidal nature. The ${ }^{1} \mathrm{H}$ NMR spectra of compound 3 (table 4.3) revealed the presences of six methyl 
groups in the up field region showing that the compound is aliphatic and may be steroidal or triterpenoidal compound. The spectrum indicated the presence of a multiplet at $\delta 3.52$ ppm, which was assigned for $\mathrm{H}-3$ indicating its steroidal nature. An olefinic proton appeared as broad singlet at $5.33 \mathrm{ppm}$, which was assigned for $\mathrm{H}-6$ in ring $\mathrm{B}$ suggesting the presence of a $\Delta 5$-3-hydroxy sterol. The spectrum indicated the presence of two tertiary methyl protons signals at $0.68,1.01 \mathrm{ppm}$, corresponding to (Me-18 and Me-19) respectively. The side chain signals appeared at $\delta 0.92(3 \mathrm{H}, \mathrm{d}, \mathrm{J}=6.4$ $\mathrm{Hz}, \mathrm{Me}-21), 0.83$ (3H, d, J = 6.8 Hz, Me-26), $0.81(3 \mathrm{H}, \mathrm{d}, \mathrm{J}=6.9 \mathrm{~Hz}, \mathrm{Me}-27), 0.85(3 \mathrm{H}, \mathrm{t}, \mathrm{J}=$ $7.8 \mathrm{~Hz}, \mathrm{Me}-29)$ suggesting that the sterol has a stigmast-5-en-3-ol skeleton. Based on all these spectral data, compound $\mathbf{3}$ is $\beta$-sitosterol which was isolated previously from same plant species by Halim and his co-workers.

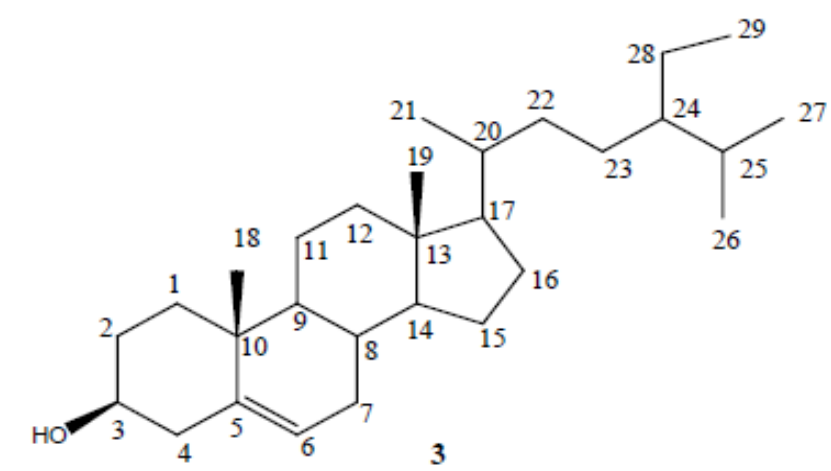

Table $3{ }^{1} \mathrm{H}$ NMR of Compound 3

\begin{tabular}{|c|c|c|}
\hline H atom & $\delta$ value, ppm & $\begin{array}{c}\text { Integration, multiplicity } \\
(\mathrm{J}, \mathrm{Hz})\end{array}$ \\
\hline 3 & 3.52 & $1 \mathrm{H}, \mathrm{m}, 1 \mathrm{H}$ \\
\hline 6 & 5.35 & $1 \mathrm{H}, \mathrm{m}, 1 \mathrm{H}$ \\
\hline $\mathrm{Me}-18$ & 0.69 & $3 \mathrm{H}, \mathrm{S}$ \\
\hline $\mathrm{Me}-19$ & 1.01 & $3 \mathrm{H}, \mathrm{S}$ \\
\hline $\mathrm{Me}-21$ & 0.92 & $3 \mathrm{H}, \mathrm{d}, 6.4$ \\
\hline $\mathrm{Me}-26$ & 0.83 & $3 \mathrm{H}, \mathrm{d}, 6.8$ \\
\hline $\mathrm{Me}-27$ & 0.81 & $3 \mathrm{H}, \mathrm{d}, 6.9$ \\
\hline $\mathrm{Me}-29$ & 0.85 & $3 \mathrm{H}, \mathrm{t}, 7.8$ \\
\hline
\end{tabular}

\section{Structure Elucidation of Compound 4}

Compound 4 was isolated as white crystals; m.p $170^{\circ} \mathrm{C}$ also it gave a violet color upon spraying with $p$-anisaldehyde-sulphoric acid reagent indicating it's steroidal or triterpenoidal nature. The ${ }^{1} \mathrm{H}$ NMR spectrum of compound 4 (table 4) is identical with the spectrum of compound 3 in addition to two olefinic protons which appeared as double of doublet at $\delta$ 5.1, $5.00 \mathrm{ppm}$, respectively, which were assigned for (H-22 and $\mathrm{H}-23)$. The spectrum suggesting the presence of a $\Delta 5,22-3$-hydroxy sterol. The $\mathrm{H}-20$ and $\mathrm{H}-24$ appeared as a multiplet at $\delta 2.24$ and $2.00 \mathrm{ppm}$, respectively due to their allylic position. Thus, all the previous data support that the compound 4 is stigmast-5, 22-dien-3-ol which is known as stigmasterol which was isolated previously from the same plant species by Halim and his group.

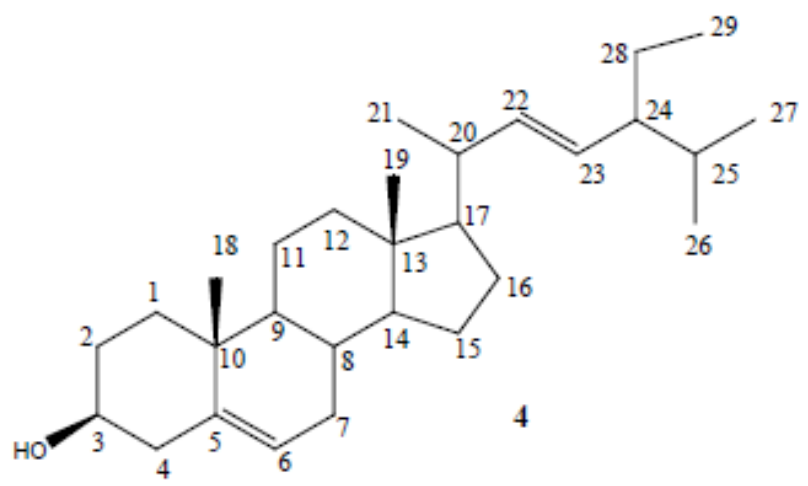

Table $4{ }^{1} \mathrm{H}$ NMR of compound 4 


\begin{tabular}{|c|c|c|}
\hline H atom & $\delta$, value, ppm & $\begin{array}{c}\text { integration, multiplicity } \\
(\mathrm{J}, \mathrm{Hz})\end{array}$ \\
\hline 3 & 3.52 & $1 \mathrm{H}, \mathrm{m}$ \\
\hline 6 & 5.35 & $1 \mathrm{H}, \mathrm{m}$ \\
\hline $\mathrm{Me}-18$ & 0.69 & $3 \mathrm{H}, \mathrm{s}$ \\
\hline Me-19 & 1.01 & $3 \mathrm{H}, \mathrm{s}$ \\
\hline $\mathrm{Me}-21$ & 0.92 & $3 \mathrm{H}, \mathrm{d}, 6.4$ \\
\hline 22 & 5.00 & $1 \mathrm{H}, \mathrm{dd}, 8,14$ \\
\hline 23 & 5.21 & $1 \mathrm{H}, \mathrm{dd}, 8,14$ \\
\hline $\mathrm{Me}-26$ & 0.82 & $3 \mathrm{H}, \mathrm{d}, 7$ \\
\hline $\mathrm{Me}-27$ & 0.83 & $3 \mathrm{H}, \mathrm{d}, 7$ \\
\hline $\mathrm{Me}-29$ & 0.97 & $3 \mathrm{H}, \mathrm{t}, 7$ \\
\hline
\end{tabular}

\section{References}

1. Ahmed S. A.; Ross S. A.; Slade D., Radwan M. M. Zulfiqar F, Matsumoto R. R; Xu Y. T, Viard E, Speth R. C, Karamyan V. T., ElSohly M. A. Cannabinoid ester constituents from high-potency Cannabis sativa. J. Nat. Prod. 2008; 71: 536-42.

2. Ghosh A., Ghosh T. Herbal drugs of abuse. Syst. Rev. Pharm. 2010; 1: 141-145.

3. McClatchey W. C., Mahady G. B., Bennett B. C., Shiels L., Savo V. Ethnobotany as a pharmacological research tool and recent developments in CNS-active natural products from ethnobotanical sources. Pharmacol. Ther. 2009; 123: 239-54.

4. Patel J, Amrutiya J, Bhatt P, Javia A, Jain M, Misra A. Targeted delivery of monoclonal antibody conjugated docetaxel loaded PLGA nanoparticles into EGFR overexpressed lung tumour cells. Journal of Microencapsulation. 2018;35(2):204-17.

5. Vhora I, Patil S, Bhatt P, Misra A. Protein- and Peptide-drug conjugates: an emerging drug delivery technology. Advances in protein chemistry and structural biology. 2015;98:1-55.

6. Mangal M., Sagar P., Singh H, Raghava G. P. S., Agarwal S. M. NPACT: Naturally occurring plantbased anti-cancer compound-activity-target database. Nucleic Acids Res. 2013; 41: D1124-D1129.

7. Abdullaev F. I., Espinosa-Aguirre J. J. Biomedical properties of saffron and its potential use in cancer therapy and chemoprevention trials. Cancer Detect. Prev. 2004; 28: 426-32.

8. Baker J. T., Borris R. P., Carte B., Cordell G. A, Soejarto D. D, Cragg G. M, Gupta M. P, Iwu M. M,
Madulid D. R, Tyler V. E. Natural product drug discovery and development - New perspectives on international collaboration. J. Nat. Prod. 1995; 58: 1325-57.

9. Amin A, Gali-Muhtasib H, Ocker M., SchneiderStock R. Overview of major classes of plant-derived anticancer drugs. Int. J. Biomed. Sci. (Pomona, CA, U. S.) 2009; 5:1-11.

10. Lee K. H. Current developments in the discovery and design of new drug candidates from plant natural product leads. J. Nat. Prod. 2004; 67: 273-83.

11. Cragg G. M., Newman D. J. Plants as a source of anti-cancer agents. J. Ethnopharmacol. 2005; 100: $72-9$.

12. Lee K. H. Anticancer drug design based on plantderived natural products. J. Biomed. Sci. (London, U. K.) 1999; 6:236-50.

13. Mahidol C, Ruchirawat S, Prawat H., Pisutjaroenpong S, Engprasert S, Chumsri P, Tengchaisri T., Sirisinha S., Picha P. Biodiversity and natural product drug discovery. Pure Appl. Chem. 1998; 70:2065-72.

14. Cragg G. M. Paclitaxel (Taxol): a success story with valuable lessons for natural product drug discovery and development. Med. Res. Rev. 1998; 18:315-31.

15. Bhatt P, Vhora I, Patil S, Amrutiya J, Bhattacharya C, Misra A, et al. Role of antibodies in diagnosis and treatment of ovarian cancer: Basic approach and clinical status. Journal of controlled release : official journal of the Controlled Release Society. 2016;226:148-67 